\title{
Pemberdayaan Kelompok Pengelola Wisata Dalam Upaya Peningkatan Pemanfaatan Wisata Mangrove di Desa Kedungasri Kecamatan Tegaldlimo Kabupaten Banyuwangi
}

\author{
Munawir $^{1}$, Mahbub $^{2}$, Masnida $^{3}$ \\ ${ }^{1}$ Fakultas Ekonomi dan Bisnis Islam, ${ }^{2}$ Fakultas Tarbiyah dan Keguruan, \\ ${ }^{3}$ Fakultas Dakwah dan Komunikasi \\ IAI Darussalam Blokagung Banyuwangi \\ Email: 1munawiriaida@gmail.com, ${ }^{3}$ Mahbubnawawi007@gmail.com, \\ 2masnidaalshiraj@yahoo.co.id,
}

\begin{abstract}
Based on field studies, there are several problems faced by the community in Kedungasri Village, Dusun Persen, especially the Kaliwatu hamlet community, Tegaldlimo District, Banyuwangi Regency, including: 1) Lack of community response to the development of mangrove tourism. 2) Lack of public insight into the benefits of mangrove forests. 3) The mindset of society that is less advanced, innovative, and creative. 4) Lack of group group management of mangrove tourism. After the socialization of the program "Renovation of mangrove tourism facilities" which was followed by the community around the mangrove tourism, it had a positive impact on resolving the problem of renovating the tourist facilities, this empowerment received a positive response from the Kaliwatu hamlet community because it beautified the mangrove tourism in the Kaliwatu hamlet, Dusun Persen. Kedungasri Village, Tegaldlimo District, Banyuwangi Regency.
\end{abstract}

Keywords: Empowerment, Mangrove Forest, Kedungasri Village

\section{Pendahuluan}

Desa Kedungasri merupakan salah satu desa yang berada di kecamatan Tegaldlimo Kabupaten Banyuwangi. Desa ini memiliki tiga dusun yaitu: Dusun Persen, Dusun Dambuntung, dan Dusun Pondokasem. Desa Kedungasri terletak di bagian timur Kecamatan Tegaldlimo, Kabupaten Banyuwangi, provinsi Jawa Timur. ${ }^{1}$

${ }^{1}$ Profil Desa Kedungasri, (2019) 
Desa Kedungasri memiliki potensi baik dibidang sumber daya manusia, seperti petani yang mahir dalam menanam padi, memiliki keahlian dalam pengelolaan sawah ketika musim hujan dan kemarau. Dibidang sumber daya alam, desa Kedungasri memiliki luas wilayah pertanian yang sangat besar, luas wilayah pertanian baik sawah kategori basah dan kering sejumlah $52,15 \%$. Desa Kedungasri ini juga memilki kawasan hutan lindung yang luas sebesar 44,05\% dan dibidang kelembagaan, seperti kelompok tani, muslimatan, dan kelompok PKK. Akan tetapi belum berjalan secara optimal, disebabkan dari $60 \%$ masyarakat usia produktif berkerja masih adanya pengangguran sebanyak 40\% yang mayoritas adalah ibu rumah tangga dikarenakan minimnya pendidikan dan kreatifitas. ${ }^{2}$

Letak geografis desa Kedungasri sebelah utara berbatasan dengan desa kedunggebang berbatasan dengan kecamatan Muncar. Sebelah timur desa Kedungasri berbatasan dengan wilayah Teluk Pang-Pang dan semenanjung Sembulung yang merupakan kawasan hutan lindung desa Kalipait, bebatasan dengan Samudera Indonesia. Sebelah barat berbatasan dengan desa Kedungwungu, kecamatan Purwoharjo. Sebelah selatan berbatasan dengan desa Kalipait, kecamatan samudera Indonesia. Luas wilayah desa Kedungasri kurang lebih mencapai $2.034,71 \mathrm{Ha}$ yang terdiri dari tiga dusun, antara lain Dusun Persen, Dusun Dambuntung, Dusun Pondok Asem. Masing-masing dusun dibatasi dengan hamparan persawahan yang mayoritas ditanami padi. $^{3}$

Tradisi yang dilaksanakan sebagai kegiatan yang menjadi rutinitas masyrakat desa Kedungasri dimana kegiatan-kegiatan tersebut sudah ada sejak nenek moyang zaman dahulu dan menjadi warisan budaya desa Kedungasri diantaranya: 1) Petik laut yang dilakukan pada setiap bulan Muharram tanggal 15 keatas. Petik laut ini merupakan suatu ucapan syukur

\footnotetext{
${ }^{2}$ Profil Desa Kedungasri, (2019)

${ }^{3}$ Profil Desa Kedungasri, (2019)
} 
kepada tuhan dengan cara sedekah laut, karena dalam hal ini tidak hanya umat islam yang mengikuti tradisi ini, tapi umat hindu juga ikut serta. 2) Bersih desa, tradisi ini dilaksanakan pada bulan Muharram. Dalam rangkaian tradisi bersih desa berisi doa lintas agama, jadi semua agama yang ada di desa kedungasri diberi kesempatan untuk berdoa bersama sesuai keyakinan masing-masing. 3) Baritan, baritan adalah tradisi slametan dalam rangka meminta hujan. Kegiatan ini dilaksanakan pada saat masuknya musim tanam. 4) Pawedatan, pawedatan adalah tradisi umat hindu, tradisi ini dalam rangka ulang tahun pura. Dilaksanakan tidak serempak karena disesuaikan dengan waktu pembuatan pura. 5) Bapang hias, bapang hias adalah tradisi tahunan yang diisi dengan kegiatan festiv al layang-layang. Pelaksanaan kegiatan ini biasanya pada bulan antara Oktober dan November. 6) Purnomo, purnomo adalah kegiatan doa orang hindu yang dilaksanakan pada setiap bulan purnama. 7) Tilem, tilem adalah kegiatan doa orang hindu yang dilaksanakan pada setiap akhir bulan. 8) Tahlilan atau yasinan, adalah kegiatan rutinitas umat islam yang dilaksanakan pada setiap malam jumat. 9) Darma santi, adalah kegiatan umat hindu yang dilaksanakan pada setiap malam kliwon dalam satu minggu.

Desa Kedungasri merupakan desa yang mayoritas penduduknya bermata pencaharian sebagai petani. Luas wilayah persawahan dan perkebunan mencapai 52,15\% dari keseluruhan luas wilayah desa Kedungasri. Pada musim hujan maka para petani mayoritas menanam padi, sedangkan pada musim kemarau mayoritas menanam kedelai, semangka,jagung dan melon. Untuk hasil perkebunan di dominasi buat naga dan jeruk, tapi luas wilayah perkebunan lebih sedikit dibandingkan wilayah persawahan. Pemanfaatan lahan sawah disesuaikan musim karena irigasi dan minimnya air. Ketika musim kemarau panjang semua sungai kehabisan air, sedangkan air irigasi dibagi sesuia dengan jadwalnya, sehingga kebutuhan akan banyaknya air sulit sekali. 
Selain bertani, bekebun, dan nelayan berikut adalah data mata pencaharian masyarakat desa Kedungasri :

Tabel 1. Mata Pencaharian Penduduk Desa Kedungasri Tahun 2019

\begin{tabular}{|c|l|l|l|}
\hline No & \multicolumn{1}{|c|}{ Mata Pencaharian } & \multicolumn{1}{|c|}{ Laki-laki } & \multicolumn{1}{|c|}{ Perempuan } \\
\hline 1 & Petani & 2.315 Orang & 1.350 Orang \\
\hline 2 & Buruh Tani & 867 Orang & 351 Orang \\
\hline 3 & Pegawai Negeri Sipil & 51 Orang & 37 Orang \\
\hline 4 & Pedagang Keliling & 40 Orang & 25 Orang \\
\hline 5 & Peternak & 120 Orang & - \\
\hline 6 & Montir & 7 Orang & - \\
\hline 7 & Dokter Swasta & 1 Orang & - \\
\hline 8 & Bidan Swasta & - & 28 Orang \\
\hline 9 & Perawat Swasta & 3 Orang & 20 Orang \\
\hline 10 & TNI & 1 orang & - \\
\hline 11 & POLRI & 1 Orang & - \\
\hline 12 & Pensiuanan TNI & - & - \\
\hline 13 & Jasa Pengobatan Alternatif & 2 Orang & - \\
\hline 14 & Karyawan Perusahaan & 37 Orang & 21 Orang \\
\hline 17 & Sopir & 30 Orang & - \\
\hline 18 & Tukang Cukur & 15 Orang & - \\
\hline
\end{tabular}

(Sumber : Profil Desa Kedungasri, 2019)

Angka pengangguran di desa Kedungasri relatif kecil, karena banyaknya lapangan pekerjaan dari sektor pertaniaan, perkebunan, dan nelayan. Pengagguran di dominasi oleh ibu rumah tangga yang hanya sebagai ibu rumah tangga saja yang tidak memiliki kegiatan. Selain itu untuk kegiatan produksi rumah tangga sangat minim, dan juga kreativitas yang tertinggal karena pengalaman dan pendidikan.

Potensi sektor basis di Kabupaten Banyuwangi hasil analisis Tipologi klassen menunjukkan sektor yang dikategorikan sebagai sektor maju dan tumbuh pesat (sektor prima) adalah Sektor Pertanian dan sektor yang 
terbelakang adalah sektor Industri Pengolahan, Perdagangan, Hotel dan Restoran, Pengangkutan dan Komunikasi, dan Jasa-jasa. ${ }^{4}$

Berdasarkan studi di lapangan, ada beberapa masalah yang dihadapi oleh masyarakat di Desa Kedungasri, Dusun Persen, khususnya masyarakat pedukuhan kaliwatu diantaranya: 1) Kurangnya respon masyarakat terhadap pengembangan wisata mangrove. 2) Kurangnya wawasan masyarakat terhadap manfaat hutan mangrove. 3) Pola pikir masyarakat yang kurang maju, inovatif, dan kreatif. 4) Kurangnya kekompokan kelompok pengelola wisata mangrove.

\section{Metode}

Pemberdayaan ini menggunakan pendekatan Participatory Action Research (PAR). ${ }^{5}$ Dengan melakukan penggalian kembali terhadap permasalahan yang terjadi. Pada uraian ini akan dipaparkan beberapa aksi yang dilakukan oleh tim pendamping sebagai langkah awal untuk menggali dan mencarikan solusi terhadap permasalahan yang ada di Desa Kedungasri Kecamatan Tegaldlimo Kabupaten Banyuwangi tersebut.

\section{Permasalahan Desa Kedungasri Secara Spesifik}

Permasalahan yang selama ini sangat dirasakan oleh masyarakat Desa Kedungasri khususnya pedukuhan Kaliwatu. Permasalahan ini kami dapatkan dari narasumber Bapak Imam Syafi'i sebagai Ketua pelaksana pengembangan wisata mangrove Desa Kedungasri pada tanggal 15 September 2019. Selain Bapak Imam Syafi'i kami juga mendapatkan

4 JAUHARIYAH, Nur Anim. Kebijakan Pengentasan Kemiskinan Melalui Kajian Potensi Sektor Basis Di Kabupaten Banyuwangi. Jurnal Darussalam: Jurnal Pendidikan, Komunikasi dan Pemikiran Hukum Islam, [S.l.], v. 7, n. 1, p. 112-126, sep. 2015. ISSN 2549-4171. Available at: <http://ejournal.iaida.ac.id/index.php/darussalam/article/view/54>. Date accessed: 15 dec. 2020.

5 INAYAH, Nurul et al. Pemberdayaan Masyarakat Dalam Usaha Peningkatan Pendapatan Keluarga Sejahtera (UPKKS). LOYALITAS, Jurnal Pengabdian Kepada Masyarakat, [S.l.], v. 2, n. 1, p. 112-123, may 2019. ISSN 2621-4687. Available at: <http://ejournal.iaida.ac.id/index.php/loyal/article/view/409>. Date accessed: 15 dec. 2020.

Pemberdayaan Kelompok Pengelola Wisata Dalam Upaya Peningkatan Pemanfaatan 
informasi dari Bapak Suryat Mojo sebagai ketua RT daerah wisata mangrove tersebut, dan juga ketua kelompok satu pengelola wisata mangrove. Kemudian kami mendapatkan informasi tambahan dari Bapak Katimin selaku ketua kelompok dua pengelola wisata mangrove. Menurut beliau bertiga wisata mangrove ini sudah pernah berjalan pada tahun 2017 karena adanya perbedaan pandangan dan pendapat yang melahirkan permasalahpermasalahan dan dapat menyebabkan berjalannya pengelolaan wisata mangrove tersebut kurang maksimal dan akhrinya berhenti. Permasalahanpermasalahan tersebut yaitu :

1) Mindset Masyarakat Yang Tertinggal

Menurut bapak Suryat sebagai ketua RT, masyarakat sekitar wilayah wisata memiliki mindset yang tertinggal, mereka mamiliki pola pikir yang praktis dan instant kurang adanya kesemangatan dalam mengembangkan dan menggali potensi yang ada di wilayahnya. Tertinggalnya mindset masyarakat dikarenakan pendidikan yang rendah, mayoritas masyarakat hanya sekolah sampai bangku sekolah dasar. Kurangnya mindset masyarakat dusun Persen dukuh Kaliwatu itu adalah faktor utama kegagalan dalam mengelola wisata mangrove. Bentuk pendekatan dan sosialisasi internal sebenarnya sudah dilakukan oleh Bapak suryat selaku ketua RT. Tapi dalam usaha tersebut keterbukaan hati masyarakat untuk menerima hal baru masih pesimis. Dari usaha tersebut pak suryat hanya mendapatkan beberapa orang saja yang beliau kumpulkan menjadi sebuah kelompok KUB (kelompok usaha berdagang). Menurut pak Imam, selaku ketua pelaksana pengelola wisata mangrove, bahwa masyarakat setempat masih belum bisa berfikir lanjut dan berkembang. Untuk pemuda yang ada di wilayah tersebut juga kurang memiliki semangat dalam membuat hal baru. 
2) Kurangnya Pengetahuan Masyarakat Terhadap Pemanfaatan Wisata Mangrove

Manfaat hutan mangrove sangat besar baik bagi kehidupan manusia dan ekosistem kehidupan. Pemahaman masyarakat sangat kurang terhadap tersebut, terbukti dengan adanya penebangan liar pohon mangrove yang digunakan masyarakat untuk kebutuhan hidup seperti rumah dan kayu bakar. Hal tersebut terjadi sebelum adanya pengelolaan wilayah wisata dan perhatian dari pemerintah.

Pemanfatan wisata mangrove sangat membantu dalam perekonomian masyarakat setempat, selain itu untuk pengawasan kelestarian hutan mangrove akan terjaga dengan baik.

3) Kurang Maksimalnya Kelompok Pengelola Wisata

Berdasarkan informasi yang kami dapatkan dari berbagai sumber bahwa kelompok pengelola wisata mangrove adalah dua kelompok KUB yaitu KUB Barokah yang di ketua pak Katimin dan KUB Sidorukun yang diketuai Pak Suryat. Koordinasi dari dua kelompok yang kurang baik dan komunikasi yang kurang tejaga menyebabkan kekompakan dan kerjasama tidak solid lagi. Selain itu kerjasama dengan pemuda setempat kurang baik. Sedangkan pelaksana pengelola wisata yang diketuai oleh Pak imam juga kurang berkoordinasi dengan baik. Dengan keadaan yang seperti ini, dan terus berlanjut tanpa adanya jalan keluar akhirnya pengelolaan wisata ini berhenti.

4) Perawatan Sarana dan Prasarana Yang Kurang Maksimal Pada awal pembukaan wisata yang di kelola dua kelompok KUB tersebut maka sudah pasti adanya beberapa sarana dan prasarana yang sudah dibuat dan diadakan. Seperti halnya kamar mandi, pos penjagaan tiket, trek bambu menuju mangrove , dan sport selvi. Tapi 
pada kenyataannya perawatan semua itu kurang maksimal, sehingga banyak yang tidak terawat dan rusak tidak dapat digunakan lagi.

5) Pendanaan Wisata Mangrove Yang Kurang

Pendanaan merupakan salah satu hal yang sangat penting untuk keberlangsungan pengelolaan wisata ini. Untuk pendanaan pengelola wisata yang sudah pernah berjalan adalah swadaya kelompok. Hal tersebut merupakan suatu yang sangat berat, karena dalam membangun wisata mangrove ini harus adanya dana yang besar. Dalam hal ini masyarakat setempat tidak menginginkan pendanaan dari investor karena akan mempersulit perkembangan perekonomian masyarakat. Tapi ketika pendanaan dari swadaya masyarakat juga tidak berjalan. Beberapa tahun yang lalu dari KUB ini mengajukan proposal kepada dinas perikanan, dan akhirnya turunlah dana yang digunakan untuk menimbun jalan, pembuatan selokan, dan trak kayu menuju hutan mangrovenya.

\section{Hasil dan Diskusi}

\section{Strategi Pelaksanaan Program}

Strategi pelaksanaan program pemberdayaan ini diawali dengan memberdayakan remaja Dusun Persen untuk membentuk organisasi yang ke depannya akan melaksanakan program pengelolaan wisata mangrove di Dusun Persen, dengan langkah-langkah sebagai berikut:

1) Observasi tempat wisata mangrove

Kami mengobservasi tempat wisata mangrove bertujuan untuk mencari informasi dan menggali permasalahan yang ada di tempat wisata tersebut. 
2) Pembentukan kelompok pengelola wisata mangrove

Setelah melakukan observasi kami melakukan pembentukan kelompok pengelola dengan tujuan kelompok tersebut dapat meneruskan pengelolaan wisata mangrove kedepannya.

3) Perencanaan program kegiatan kelompok pengelola wisata mangrove Dalam perencanaan ini kami membuat dan mengusulkan program kegiatan kelompok yang akan menjadi kegiatan rutinan kelompok. Program-program ini bertujuan untuk kegiatan rutinan kelompok, dan merupakan bentuk dari totalitas kinerja individu dalam kelompok.

4) Renovasi dan peremajaan fasilitas yang ada di wisata mangrove Renovasi dan peremajaan fasilitas ini kami kerjakan bersama kelompok pengelola wisata mangrove. Renovasi dan peremajaan ini merupakan bentuk kinerja nyata kami dan kelompok pengelola wisata dalam mengembangkan potensi wisata.

5) Publikasi wisata mangrove

Publikasi wisata mangrove ini merupakan bentuk kinerja kami dan kelompok dalam mempromosikan wisata mangrove. Publikasi ini kami lakukan dengan menggunakan media sosial. Beberapa media sosial yang kami gunakan adalah whatsapp, instagram, facebook, dan twiter.

Pada minggu pertama, mahasiswa berusaha mengetahui situasi kehidupan masyarakat di Desa Kedungasri, khususnya di Dusun Persen. Pada minggu pertama ini, mahasiswa membaur dengan masyarakat sehingga memunculkan kerjasama yang menunjukkan terbangunnya rasa saling percaya antara mahasiswa dan masyarakat. Pada minggu pertama juga, mahasiswa memperoleh data mengenai kondisi geografis dan demografis desa. Juga memperoleh gambaran masalah desa. Pada minggu ini juga, 
mahasiswa memperoleh informasi tentang kondisi ekonomi rumah tangga, profil keberagamaan masyarakat, dan data politik pembangunan desa.

Pada minggu kedua, mahasiswa berusaha memahami masalah kehidupan masyarakat dusun Persen. Mahasiswa juga dapat membentuk kalender kegiatan masyarakat dari hasil pendekatan dengan masyarakat. Mahasiswa juga dapat membuat bagan pohon masalah dan pohon harapan dari hasil observasi dengan masyarakat. Pada minggu kedua ini, mahasiswa sudah mulai melakukan rapat bersama remaja dusun Persen yang membahas kegiatan memperbaiki fasilitas wisata mangrove.

Pada minggu ketiga, mahasiswa sudah merencanakan pemecahan masalah yang ada di wilayah wisata mangrove. Adapun rencana pemecahan masalah yang ada di wilayah wisata mangrove di Dusun Persen yaitu :

1) Mengidentifikasi masalah bersama ketua RT dan tokoh masyarakat.

2) Membentuk kelompok pengelola wisata mangrove.

3) Merencanakan program kegiatan kelompok pengelola wisata mangrove.

4) Melaksanakan kerja nyata perbaikan fasilitas wisata mangrove.

5) Publikasi wisata mangrove melalui media social yang ada.

Pada minggu keempat, kegiatan terkait masalah meningkatkan pemanfaatan wisata mangrove sudah dilaksanakan dan dievaluasi. Mahasiswa juga sudah menentukan analisis terkait kendala dan solusi kegiatan meningkatkan pemanfaatan fasilitas wisata. Pada minggu keempat ini mahasiswa juga sudah menyusun laporan baik individu atau kelompok serta sudah mengumpulkan film pendek terkait program tersebut.

\section{Realisasi Waktu Pelaksanaan Program}

Kegiatan silaturrahim dan wawancara kepada tokoh masyarakat pedukuhan Kaliwatu kami laksanakan pada Hari Rabu, 11 September 2019. Bertempat di rumah Bapak Suryat Mojo ketua RT dukuh Kaliwatu, kami 
berkesempatan melakukan wawancara tentang kondisi pedukuhan Kaliwatu. Menurut beliau masalah utama dukuh ini adalah kurangnya kesadaran masyarakat tentang pentingnya manfaat wisata mangrove, selain itu pola pikir masyarakat yang belum berkembang maju, pola pikir yang masih jenuh enggan untuk berinovasi dan berkreasi.

Sebenarnya desa Kedungasri sendiri memiliki aset wisata yang luar biasa. Diantara wisata tersebut adalah Candi Purwo yang terletak di Dusun Pondokasem. Candi ini terletak ditengah huatan mangrove, akses menuju ke wisata candi purwo ini sudah bisa ditempuh dengan kendaraan ord dua. Kemudian wisata Watu Lempeng, merupakan kawasan tanah lapang ditengah-tengah hutan mangrove, karena terdapat tanah batu yang luas sehingga tidak bisa ditumbuhi tanaman mangrove sehingga terbentuklah tanah lapang. Kemudian hutan mangrove teluk pang-pang yang ada di pedukuhan kaliwatu Dusun Persen. Hutan mangrove teluk pang-pang merupakan icon wisata di desa Kedungasri. Wisata ini sempat ramai dikunjungi wisatawan lokal. Namun karena terjadinya berbagai problem yang menghambat, hingga akhirnya terbengkalai dan tutup total. Hal ini dapat dilihat dari kondisi wisata yang tidak sedap dipandang karena tempat wisata ini kurang bersih dan tertata dengan baik. Selain itu beberapa fasilitas mulai rusak dan belum ada tindak lanjut.

Kemudian kami menyampaikan rencana tersebut kepada Bapak Suryat Mojo dan sesuai saran dan anjuran beliau kami mengumpulkan pemuda dan tokoh masyarakat pedukuhan Kaliwatu pada Hari Selasa, 17 September 2019. Pada kesempatan ini kami menyampaikan pentingnya pemanfaatan wisata mangrove, hal-hal positif dari pengembangan wisata, dan dampak terhadap perekonomian masyarakat. Selanjutnya kami membentuk kelompok pengelola wisata dan membuat program-program kerja kelompok pengelola wisata. Diantara program kerja kelompok tersebut adalah rapat rutinan setiap tanggal 15 dan 30, serta kegiatan jum'at bersih. 
Untuk mengawali program kerja kelompok ini, kami dan kelompok pengelola melakukan gotong royong untuk membersihkan area wisata mangrove pada hari jum'at tanggal 20 September 2019. Selanjutnya kita merenovasi dan meremajakan fasilitas wisata yang ada disana. Seperti pengecatan pohon-pohon, jembatan, dan membuat sport selvi.

\section{Paparan Pelaksanaan Program}

Langkah-langkah pelaksanaan program sebagai berikut:

1. Pendekatan Dengan Masyarakat

Ada sebuah kutipan yang berbunyi "Tak Kenal Maka Tak Sayang" dari kutipan tersebut maka langkah kita yang pertama dan utama adalah melakukan pendekatan dengan masyarakat dengan berbagai cara seperti halnya silaturrahmi, ngobrol bareng, dan keikutsertaan dalam kegiatan kemasyarakatan. Dari cara-cara tersebut kami dapat menggali bebagai bentuk informasi, ilmu dan juga berbagai pendapat mereka tentang proggram kita. Vareasi dalam berpendapat merupakan suatu hal yang lumrah karena itu adalah rahmat Allah.

Pada awal kami sampai di Desa Kedungasri kami langsung bersilaturrahmi kepada perangkat desa, seperti Kepala Dusun, Tokoh Agama, Tokoh Masyarakat, Alumni, ketua RT, dan Juga pihak pengelola wisata mangrove. Dari situlah kami bisa mendapatkan informasi yang dapat membantu kita dalam melaksanakan program. Pada suatu kesempatan kami bersilaturrahmi dengan orang-orang penting yang pernah mengelola wisata mangrove, orang-orang tersebut adalah Bapak Suryat Mojo sebagai ketua RT dan juga ketua KUB Sido Rukun, Bapak Katimen sebagai Ketua kelompok KUB Barokah, dan Bapak Imam Syafii sebagai ketua pelaksana lapangan pengelola wisata. Dari beliau-beliau kami mendapatkan berbagai permasalah, saran dan anjuran. 
Pendekatan secara luas kami lakukan dengan mengikuti kegiatankegiatan kemasyaratan seperti tahlilan, yasinan, muslimatan, dan lain lain. Dari situ kami mendapatkan berbagai bentuk pendapat dari masyarakat. Ada yang mendukung, ada yang menjatuhkan, ada yang optimis, dan ada yang pesimis.

Sebelum kami memantapkan program kami, kami berkonsultasi kepada Kepala Dusun Persen terlebih dahulu. Dalam hal ini kami melakukan audiensi langsung dengan beliau dalam beberapa kali pertemuan. Selanjutnya kami beraudiensi dengan Bapak Suryat Mojo, Bapak Katimen, dan Bapak Imam Syaii. Menurut pandangan dan pendapat beliau sangat mensupport program kami. Dan kami pun sepakat untuk mengambil program peningkatan pemanfaatan wisata mangrove.

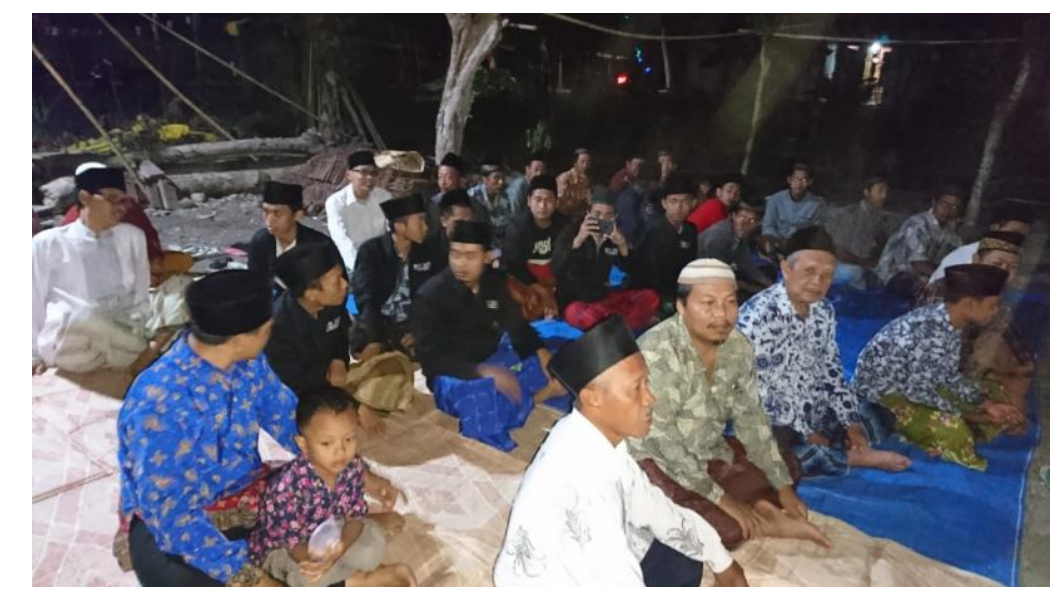

\section{Gambar 1. kegiatan pendekatan kepada masyarakat (Sumber: Dokumentasi, 2019)}

2. Pembentukan Kelompok Pengelola Wisata Mangrove dan Pembuatan Program Kelompok

Program pertama dan utama adalah pembentukan kelompok yang merupakan suatu embrio dari program ini. Pembentukan kelompok ini merupakan salah satu bentuk komitmen kami dalam mensukseskan

Pemberdayaan Kelompok Pengelola Wisata Dalam Upaya Peningkatan Pemanfaatan Wisata Mangrove di Desa Kedungasri Kecamatan Tegaldlimo Kabupaten Banyuwangi Munawir, Mahbub, Masnida 
program kami. Dengan adanya kelompok ini akan bisa melanjutkan program lanjutan dari pengelolaan wisata mangrove setelah kami tinggalkan. Dalam pembentukan kelompok ini kami melibatkan beberapa pihak-pihak terkait, diantaranya adalah :

a. Kepala Kasun Persen

Letak wilayah wisata mangrove ini berada di Dusun Persen maka dalam melaksanakan program kami harus mendapatkan persetujuan dari kepala Dusun Persen agar nantinya akan disampaikan kepada Kepala Desa. Dalam hal pembentukan kelompok dan penentuan program pengelolaan wisata kami mengikutsertakan Kepala Dusun yang pada akhirnya adalah supervisor dari keberlangsungan penegelolaan wisata ini. Menurut pak Fauzi Kepala Dusun, pengembangan wisata ini akan sangat membantu peningkatan perekonomian masyarakat karena secara tidak langsung akan memberikan lowonagan pekerjaan kepada para masyarakat. Selain itu dalam hal promosi desa akan lebih mudah karena adanya wisata.

b. Ketua RT Pedukuhan Kaliwatu

Bapak Suryat Mojo, Sebagai tuan rumah wisata mangrove maka kami harus mengikutsertakan beliau dalam pemebentukan kelompok penegelola wisata mangrove. Menurut beliau dalam peningkatan pemanfaatan wisata mangrove ini harus membentuk kelompok yang diikuti oleh orang-orang dengan totalitas kerja tinggi.

c. Tokoh Masyarakat Pedukuhan Kaliwatu

Tokoh masyarakat sangat berperan dalam perubahan mindset masyarakat. Karena mindset masyarakat di Pedukuhan Kaliwatu ini masih tertinggal. Karena alasan itu kami mengikutsertakan tokoh masyarakat dalam menghidupkan lagi potensi wisata mangrove. Dengan adanya kerjasama dengan tokoh masyarakat maka akan mempermudah jalan kelompok kedepannya. Dengan dukungan dan 
dorongan tokoh masyarakat akan menciptakan suatu kerja sama yang baik antara pengelola dan warga sekitar.

d. Tokoh Agama di Pedukuhan Kaliwatu

Dukungan dan dorongan dari tokoh agama sangat membantu dalam perkembangan wisata mangrove. Dengan alasan tersebut kami juga mengikutsertakan tokoh agama dalam pembentukan kelompok dan pembuatan program kelompok.

e. Pemuda Pedukuhan Kaliwatu

Pengembangan wisata pasti akan melibatkan pemuda maka kami pun mengikutsertakan pemuda dalam pembentukan kelompok dan pembuatan program kelompok. Dengan adanya bantuan dari para pemuda akan mempermudah dalam pekerjaan kedepannya dan keberlangsungan pengelolaan wisata mangrove.

Pertemuan ini kami beserta tokoh masyarakat, tokoh agama, dan pemuda Pedukuhan Kaliwatu ini menghasilkan struktur organisasi pengelola wisata mangrove dan program-program kelompok pengelola.

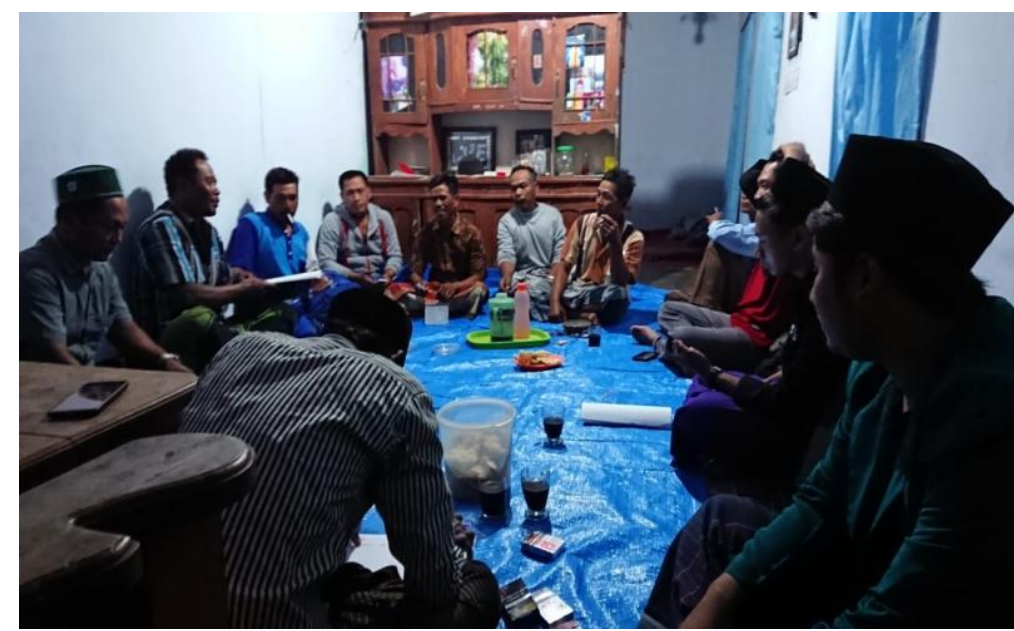

Gambar2. Pembentukan Kelompok Pengelola Wisata (Sumber: Dokumentasi, 2019)

Pemberdayaan Kelompok Pengelola Wisata Dalam Upaya Peningkatan Pemanfaatan 


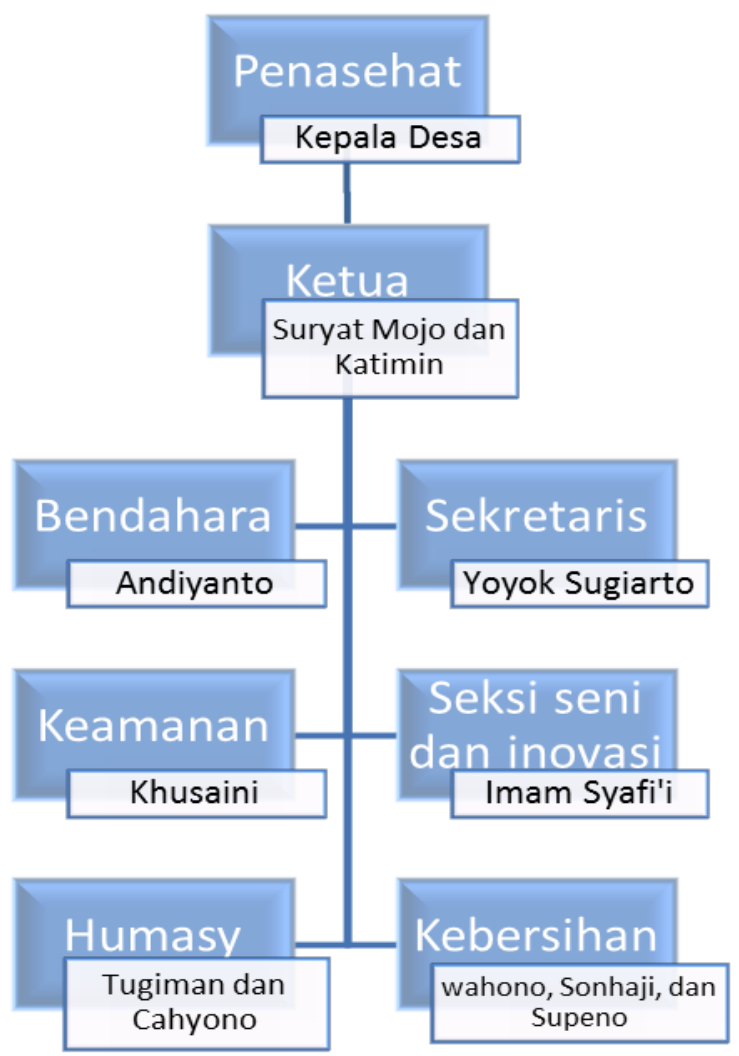

\section{Gambar 3. Struktur Organisasi Pengelola Wisata Mangrove (Sumber: Dokumentasi di Lapangan, 2019)}

Berikut adalah job discription dari struktur pengelola wisata mangrove ini :

1) Ketua

a) Memimpin kelompok Pengelola Desa Wisata.

b) Memberikan pengarahan pada anggota.

c) Mengkoordinir kegiatan - kegiatan serta bertanggung jawab mengenai pelaksanaan kegiatan.

d) Memimpin pertemuan maupun diskusi kelompok.

e) Menandatangani surat - surat.

f) Berkordinasi dan bertanggung jawab kepada Penanggung jawab 
2) Ketua Dua

a) Membantu tugas ketua.

b) Mewakili ketua dalam berbagai kegiatan maupun pertemuan apabila berhalangan hadir.

c) Berkordinasi antar seksi serta bertanggung jawab kepada ketua.

3) Sekretaris

a) Menyusun dan melaksanakan kegiatan administrasi.

b) Mempersiapkan bahan - bahan pertemuan kelompok.

c) Mengadakan hubungan dan koordinasi dengan pihak luar terkait.

d) Menghimpun dan notulasi seluruh hasil rapat dan pertemuan.

e) Bertanggung jawab kepada ketua

f) Mencatat jumlh pengunjung setiap hari

g) Mengkalkulasi peningktan dan penurunan pengunjung

4) Bendahara

a) Bertanggung jawab atas pendapatan dan pengeluaran uang.

b) Melakukan pencatatan dan pelaporan keuangan secara tertib.

c) Bertanggung jawab kepada ketua.

d) Mencari sumber dana semaksimal mungkin

e) Mengalokasikan dana sebaik mungkin

5) Seksi Seni Dan Inovasi

a) Menggali Inovasi berupa alam, kebudayaan, kesenian yang ada di Desa Wisata Kedungasri sebagai penunjang pariwisata.

b) Inventarisasi keseniaan beserta data - data.

c) Membuat usulan program kegiatan yang berhubungan dengan seni dan potensi wilayah.

d) Menciptakan kreatifitas dalam pengembangan potensi wisata 
e) Berkordinasi antar seksi serta bertanggung jawab kepada ketua.

6) Seksi Keamanan

a) Menjaga keamanan dan keselamatan pengunjung

b) Menjaga dan mengamankan barang bawaan pengunjung

c) Menyiapkan tempat parkir kendaraan pengunjung

7) Humasy

a) Menjalin hubungan yang baik dengan masyarakat sekitar

b) Menjalin kerjasama dengan pihak keamanan desa dan kecamatan

c) Membuat efent adt dan kemasyarakatan yang bersifat promosi

8) Seksi Sarana Dan Prasarana

a) Mempersiapkan segala kebutuhan untuk kegiatan pariwisata.

b) Membantu kegiatan pengurus.

c) Berkordinasi antar seksi serta bertanggung jawab kepada ketua

d) Menjaga dan melestarikan sarana dan prasrana yang ada

e) Merencanakan dan menganggarkan sarana dan prasarana yang dibutuhkan

f) Pencatatan dan inventarisasi sarana dan prasarana

9) Kebersihan

a) Menjaga kebersihan lingkungan wisata dan sekitarnya

b) Menciptakan suasana wisata yang nyaman, sejuk, dan harmonis

c) Membuat inovasi dan kreasi wisata melalui sampah wisata

d) Berkordinasi antar seksi serta bertanggung jawab kepada ketua. 
3. Program kerja kelompok pengelola wisata mangrove, sesuai keputusan program kerja kelompok pengelola

a) Kegiatan jumat bersih masyarakat dan kelompok pengelola

b) Rapat rutinan setiap tanggal 15 dan 30

c) Pemberdayaan masyarakat dengan pembinaan melalui kegiatan kemasyarakatan

d) Sosialisasi kepada masyarakat tentang wisata mangrove

4. Renovasi dan Peremajaan Fasilitas Wisata Mangrove Tahap selanjutnya setelah adanya pembentukan kelompok adalah merenovasi dan meremajakan Fasilitas wisata yang sudah ada. Hal ini sangat penting karena sebagai daya tarik kepada para wisatawan yang akan datang, sehingga para wisatawan tidak akan kecewa dengan keadaan wisata yang tidak nyaman, membosankan dan meprihatinkan. Renovasi dan peremajaan ini kami lakukan dengan senang hati, karena ini merupakan totalitas kami dalam melakukan program ini.

Hasil dari kesepakatan kelompok kami akhirnya kami mengambil keputusan beberapa tindakan dalam proses renovasi dan peremajaan ini. Diantara tindakan-tindakan itu adalah :

a) Pengecatan

Pengecatan ini kami lakukan dengan tujuan agar tempat wisata mangrove tersebut tidak terlihat gersang dan mati. Sebelum kami melakukan pengecatan kami meminta izin kepada pak RT agar semua tidak ada masalah kedepannya. Dalam hal ini kami memilih melakukan pengecatan pada jembatan, papan icon wisata mangrove, dan pepohonan yang menurut kami bisa menjadi daya tarik pengunjung. 


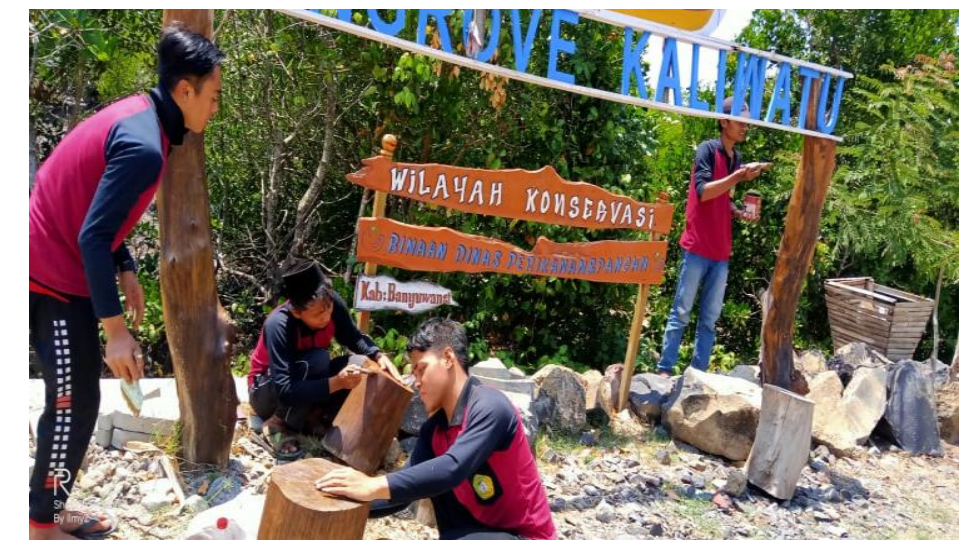

\section{Gambar 4. Pengecatan Icon Wisata Mangrove} (Sumber: Dokumentasi di Lapangan, 2019)

b) Pembuatan Spot selfy

Pembuatan spot selfy dengan tujuan agar bisa menjadi ajang foto dan merupakan suatu bentuk promosi ghoib, tanpa kita mensebar luaskan maka wisata ini akan tersebar dengan sendirinya. Diantara pembuatan spot selfy tersebut adalah pembuatan tempat duduk santai dengan latar belakang hutan mangrove. Kemudian pembuatan kata-kata yang menarik perhatian.

c) Pembuatan Papan Ucapan Datang dan Pesan Moral

Pembuatan ucapan selamat datang adalah bentuk apresiasi kita kepada para pengunjung, ini merupakan suatu daya tarik tersendiri bagi pengunjung dan orang yang akan berkunjung. Pembuatan pesan moral merupakan suatu bentuk kepedulian kami terhadap moral para pengunjung agar selalu terjaga dan tidak lupa diri.

5. Gotong Royong Membersihkan Lingkungan Wisata Mangrove Gotong royong ini kami lakukan bersama masyarakat agar adanya bentuk sinergi yang baik antara kami dan masyarakat, terutama kelompok pengelola yang sudah di buat. Dalam hal ini kami bersama masyarakat membersihkan selokan, rumput-rumput liar, dan kamar 
mandi yang tidak terawat. Dalam gotong royong ini membuat kami lebih akrab dengan masyarakat dan anggota kelompok pengelola.

6. Publikasi Wisata Mangrove Melalui Media Sosial

Publikasi melalui media sosial sangat penting dalam majunya perkembangan perduniaan maya yang didominasi oleh media sosial. Tujuan pemasaran tempat wisata yang bersifat efektif, dan efisien maka dengan dilakukan Publikasi melalui media sosial terbilang sangat tepat karena sedikit biaya dan banyak manfaatnya. Selain dari pihak kami, dari pihak kelompok pengelola wisata juga melakukan publikasi, hal ini merupakan bentuk komitmen kami dalam mengembangkan wisata mangrove di Kaliwatu Desa Kedungasri.

\section{Simpulan}

Meningkatkan Pemanfaatan Wisata Mangrove Melalui Pemberdayaan Kelompok Pengelola Wisata di Dusun Persen Desa Kedungasri Kecamatan Tegaldlimo Kabupaten Banyuwangi. Adapun pihak yang terkait dlam pemberdayaan ini adalah remaja dan tokoh masyarakat pedukuhan Kaliwatu. Dengan adanya kerjasama yang baik sangat membantu terlaksanakannya program tersebut. Mulai dari rapat-rapat yang dilaksanakan, berperan aktif dalam kegiatan gotong royong membersihkan area wisata, serta merenovasi fasilitas yang tidak layak. Setelah adanya sosialisasi program "Renovasi fasilitas wisata mangrove" yang diikuti oleh masyarakat sekitar wisata mangrove tersebut memberikan dampak positif pada penyelesaikan masalah renovasi fasilitas wisata tersebut, Pemberdayaan ini mendapatkan tanggapan positif dari masyarakat pedukuhan Kaliwatu karena memperindah kembali wisata mangrove yang ada di pedukuhan Kaliwatu Dusun Persen Desa Kedungasri Kecamatan Tegaldlimo Kabupaten Banyuwangi. 


\section{Referensi}

INAYAH, Nurul et al. Pemberdayaan Masyarakat Dalam Usaha Peningkatan Pendapatan Keluarga Sejahtera (UPKKS). LOYALITAS, Jurnal Pengabdian Kepada Masyarakat, [S.l.], v. 2, n. 1, p. 112-123, may 2019. ISSN 2621-4687. Available at: <http://ejournal.iaida.ac.id/index.php/loyal/article/view/409>. Date accessed: 15 dec. 2020.

JAUHARIYAH, Nur Anim. Kebijakan Pengentasan Kemiskinan Melalui Kajian Potensi Sektor Basis Di Kabupaten Banyuwangi. Jurnal Darussalam: Jurnal Pendidikan, Komunikasi dan Pemikiran Hukum Islam, [S.l.], v. 7, n. 1, p. 112-126, sep. 2015. ISSN 2549-4171. Available at: <http://ejournal.iaida.ac.id/index.php/darussalam/article/view/54>. Date accessed: 15 dec. 2020.

LPPM, (2019). Buku Pedoman Kuliah Kerja Nyata Participatory action reseach. LPPM-IAIDA Blokagung Banyuwangi.

Kedungasri, 2019, Buku Profil Desa Kedungasri, Kecamatan Tegaldlimo, Kabupaten Banyuwangi. 